\title{
MISTAKE AND SURETYSHIP: AVOIDING THE SPECTRE OF BRINK $V$ HUMPHRIES \& JEWELL (PTY) LTD
}

\section{Introduction}

The nettlesome matter of operative mistake and suretyships tucked away in credit applications tends to find its way into the law reports on a rather frequent basis. This phenomenon is hardly surprising because in the cut and thrust of modern commerce, and even more so in lean times, individuals are keen to apply for credit on behalf of the corporate entities which they represent, but less eager to stand in for these debts when they cannot be serviced. From the contractual perspective of mistake, these cases tend to follow a familiar pattern (compare eg, the facts of Roomer $v$ Wedge Steel (Pty) Ltd 19981 SA 538 (N); and Diners Club SA (Pty) Ltd v Thorburn 1990 2 SA $870($ (C)). Commonly, a member of a close corporation or director of a private company applies on behalf of the close corporation or company, as the case may be, for some or other form of credit from another party. Usually, within a business context, credit will not be granted without some form of security, and in these instances more often than not the representative is required to agree to a personal suretyship in favour of the creditor, which is often embodied in the credit application form itself. Once the representative has appended him or her signature to the application form, he or she inexorably finds himself or herself simultaneously bound as surety and co-principal debtor, the formal requirements for a suretyship agreement having been complied with (as prescribed by $s \quad 6$ of the General Law Amendment Act 50 of 1956).

On the whole older case law displays a reluctancy on the part of the judiciary to excuse a surety on the basis of material mistake in such circumstances, but in Brink v Humphries \& Jewell (Pty) Ltd (2005 2 SA 419 (SCA)) the Supreme Court of Appeal adopted a far more lenient approach in favour of the surety, and perhaps heralded a not too subtle change in the law. This note examines the way in which the courts have adjudicated similar cases, and specifically whether more recently they have reinforced the generally stricter approach of old or been prepared to follow the path which Brink seemed to have cleared.

\section{Caveat subscriptor and iustus error}

The caveat subscriptor rule, which features prominently in cases of suretyship and mistake, provides that a person who signs a document which embodies contractual terms may be held bound thereto on the basis of the impression of assent created by the signature (see eg, George $v$ Fairmead (Pty) Ltd 19582 SA 465 (A) 472-473). This rule finds its justification in the promotion of certainty and security in contractual relations, being "a sound 
principle of law that a man, when he signs a contract, is taken to be bound by the ordinary meaning and effect of the words which appear over his signature" (Burger v Central South African Railways 1903 TS 571578 per Innes CJ). The basis of the caveat subscriptor rule is generally considered to be the doctrine of quasi-mutual assent (or reliance theory) (see eg, Brink $v$ Humphries \& Jewell (Pty) Ltd supra par 2; Christie The Law of Contract in South Africa 5ed (2006) 175; and Lewis "Caveat Subscriptor and the Doctrine of Justus Error" 1987 SALJ 371 375), although it tends to display stronger affinities to the declaration theory (see Pretorius "The Basis and Underpinnings of the Caveat Subscriptor Rule" 2008 THRHR 660).

However, the caveat subscriptor rule is not absolute and within the realm of mistake it is usually tempered by the iustus error doctrine which provides relief to the signatory who signs a document while labouring under an operative and reasonable error (see eg, Shephard $v$ Farrell's Estate Agency 1921 TPD 62; and Du Toit v Atkinson's Motors Bpk 19852 SA 893 (A)). Generally though, in keeping with a cautious approach to a defence of justifiable mistake (see generally Christie 314-315), a signatory will not lightly be relieved from liability under a contract to which she apparently assented in this manner (compare eg, Burger $v$ Central South African Railways supra 578-579; George v Fairmead (Pty) Ltd supra 472; see further Kerr The Principles of the Law of Contract 6ed (2002) 102-103 especially fn 312; and cf Woker "Caveat Subscriptor. How Careful are We Expected to Be?" 2003 SA Merc LJ 109 110-111). The caveat subscriptor rule and iustus error approach require careful balancing: Undue emphasis on form will undoubtedly prejudice unwitting signatories and encourage sharp practices on the part of contract enforcers, while a too lenient approach will permit signatories to evade the consequences of careless or reckless conduct and promote uncertainty (cf Lubbe and Murray Farlam and Hathaway Contract: Cases, Materials and Commentary (1988) 181).

\section{Caveat subscriptor and early case law}

The caveat subscriptor rule was applied strictly, and even harshly, when it initially surfaced in case law. It mattered little, for instance, that the signatory could not read or write the language contained in the document (see Bhikhagee $v$ Southern Aviation (Pty) Ltd 19494 SA 105 (E)), or that the document contained technical Latin phrases which impacted severely on the rights of the signatory (see Mathole $v$ Mothle 19511 SA $256(T)$ ), the signatory would be held bound as a matter of course (see further the discussion of early case law by Hutchison "Traps For the Unwary': When Careless Errors are Excusable" in Glover (ed) Essays in Honour of AJ Kerr (2006) 39 41-42). The reason for this rather rigid approach was that the rule was borrowed from English law (see seminally Burger $v$ Central South African Railways supra 579), and English law viewed the matter from a decidedly objective viewpoint (see eg, Parker $v$ South Eastern Ry (1877) 2 CPD 416 421; L'Estrange v F Graucob Ltd [1934] 2 KB 394 403; and further Spencer "Signature, Consent and the Rule in L'Estrange v Graucob" 1973 CLJ 104; and Pretorius 2008 THRHR 666). 


\section{$4 \quad$ Traditional approach and suretyships}

With the emphasis on legal certainty and consistency, generally the courts have been fairly strict in applying the caveat subscriptor rule to suretyships inserted in credit applications on behalf of corporate entities (see eg, Diners Club SA (Pty) Ltd v Thorburn supra 874-875; Roomer v Wedge Steel (Pty) Ltd supra 543; Blue Chip Consultants (Pty) Ltd v Shamrock 20023 SA 231 (W) 240-241; and cf Khan $v$ Naidoo 19893 SA 724 (N)), as well as suretyships contained in separate documents to secure the contractual obligations of corporate entities (see eg, Tesoriero $v$ Bhyjo Investments Share Block (Pty) Ltd 20001 SA 167 (W); and Advanced Mechanical \& Lubrication Technology (Pty) Ltd v Conradie Ontwikkelings BK [2006] JOL $16692(\mathrm{~T}))$.

Burger AJ aptly summarised what may be referred to as traditional judicial sentiment in Diners Club SA (Pty) Ltd v Thorburn (supra 874D-F):

"I turn now to the first defence mentioned above, which is characterised in the respondent's heads of argument as justus error. It is again trite law that a party who puts his signature to a document containing contractual terms has a very limited scope for escaping liability by saying that he did not know or understand the terms of the document (George v Fairmead (Pty) Ltd 1958 (2) SA 465 (A) at 472). The Courts have allowed such a defence only in cases where the other party was in some way to blame for this mistake. Most commonly, such blame would exist where the other party has itself created or fostered the mistake by previously advertising or describing the transaction in terms at variance with preve contained in the document (see for example Du Toit $v$ Atkinson's Motors Bpk 1985 (2) SA 893 (A); Spindrifter (Pty) Ltd v Lester Donovan (Pty) Ltd 1986 (1) SA $303(A))$."

The question of suretyships tucked away in credit applications enjoyed the attention of the Supreme Court of Appeal in Stiff $v Q$ Data Distribution (Pty) Ltd (2003 2 SA 336 (SCA)), but unfortunately this decision rests on rocky ground. The facts are typical: the sole member of a close corporation signed a credit application on its behalf which incorporated a suretyship provision in terms of which he bound himself or herself as surety and co-principal debtor for the debts of the close corporation. When sued on the basis of the suretyship the member alleged that the suretyship provision had not come to his notice and that he never intended binding himself as surety. The court $a$ quo rejected these contentions and granted judgment against the member. Although the Supreme Court of Appeal dismissed his appeal on the basis that at the time of signing the member was aware of the suretyship clause and hence actually agreed to it (par 16), the decision is in fact consonant with the traditional application of the caveat subscriptor rule (an objective basis for liability). For one thing, it displays a fairly intolerant disposition toward recalcitrant sureties within the circumstances under discussion; and for another, the actual basis for liability in the circumstances is more appropriately explained in terms of the caveat subscriptor rule (see Christie 175; and Pretorius "General Principles of the Law of Contract" 2007 Annual Survey 469 476). The signatory simply could not prove a justifiable mistake in the circumstances (cf par 16 of the decision) and was thus held bound on the basis of constructive (rather than actual) assent evidenced by his signature on the document. 


\section{$5 \quad$ Conflicting decisions at provincial level}

As one would expect, there have been justifiable exceptions to the caveat subscriptor rule within the context of suretyships contained in credit applications and other contractual documents. There are examples where the creditor has fostered the mistake, for instance, by not pointing out a suretyship clause in a contract, when in the circumstances it had a duty to do so (misrepresentation by omission: compare eg, Kempston Hire (Pty) Ltd $v$ Snyman 19884 SA 465 (T) 468H). Such instances slot fairly comfortably into the realm of excusable mistake without causing problems (see further Hutchison 46). But in Keens Group Co (Pty) Ltd v Lötter (1989 1 SA 585 (C)) the court intimated that the furnishing of a document, drafted in such a manner as to set a trap for the unwary signatory, could justify a finding of iustus error on the part of the signatory. In casu the signatory admitted negligence on his part in not reading the credit application before signing it (589J) even though he had ample time to do so $(591 \mathrm{~F})$, and signed the document in the absence of the other party whilst not under any pressure. Despite such carelessness, the signatory's mistake was regarded as reasonable (592D).

The Keens decision drew strong reaction from some quarters (see especially Sharrock "Inappropriate Wording in a Contract: A Basis for the Defence of lustus Error?" 1989 SALJ 458; and generally Otto "Verskuilde Borgstellings in Standaardkontrakte en lustus Error" 2005 TSAR 805 810811; and Hutchison 46-47). The courts were at times clearly disparaging about it (see eg, Tesoriero v Bhyjo Investments Share Block (Pty) Ltd supra $180 \mathrm{~F}-\mathrm{G}$ ) and at pains to distinguish it on the facts (see eg, Diners Club SA (Pty) Ltd $v$ Thorburn supra 875). Nevertheless, a similar approach to the one adopted in Keens was followed in Diners Club SA (Pty) Ltd v Livingstone (1995 4 SA 493 (W)) (for an evaluation of this case see Cilliers and Luiz "Caveat Subscriptor - Beware the Hidden Suretyship Clause: Diners Club SA (Pty) Ltd v Livingstone 19954 SA 493 (W)" 1996 THRHR 168). In the result, there are conflicting decisions at provincial level, but on balance the traditional approach seems to have been the more dominant.

\section{$6 \quad$ Brink v Humphries \& Jewell (Pty) Ltd}

In Brink v Humphries \& Jewell (Pty) Ltd (supra) the Supreme Court of Appeal had the opportunity to express itself on the question of excusable mistake and suretyships incorporated in credit applications, and proceeded to set the cat amongst the pigeons by effectively affirming the approach in Keens Group Co (Pty Ltd v Lötter (supra). In Brink the signatory was a director of a company who signed a credit application on behalf of the company without reading it, although he had ample opportunity to do so. The form imposed a suretyship obligation on the signatory which secured the company's indebtedness to the creditor. Subsequently, relying on the caveat subscriptor rule, the creditor successfully claimed the debts of the company from the signatory whose plea of justifiable mistake failed in the circumstances. However, on appeal Cloete JA, delivering the majority judgment, upheld the signatory's appeal on the basis of iustus error because "the form was a trap 
for the unwary and the appellant [signatory] was justifiably misled by it" (426C).

The court reached this conclusion despite the fact that, amongst other things, the signatory set up his own mistake by not reading a fairly straightforward one page document and even signed right over the suretyship clause in the process. In a dissenting decision Navsa JA found that the form could not be described as a trap or misrepresentation (par 35), and warned that to permit the signatory to escape liability in the circumstances would "open the door to abuse and possible uncertainty" $(430 \mathrm{H})$ (for critical analyses of this decision see Hutchison 47-52; Otto 2005 TSAR 811-814; Bhana and Nortjé "General Principles of Contract" 2005 Annual Survey 196 208-214; and Pretorius "Caveat Subscriptor and Iustus Error: Brink v Humphries \& Jewell (Pty) Ltd 20052 SA 419 (SCA)" 2006 THRHR 675).

Apart from the questionable finding of excusable mistake on the facts (see Bhana and Nortjé 2005 Annual Survey 212-214; and Pretorius 2006 THRHR 680-683), Brink was also problematic in regard to its formulation of the iustus error approach. Usually a material mistake is regarded as reasonable when it is engendered by the positive misrepresentation of the contract enforcer, or a misrepresentation by silence where the contract enforcer was aware or ought as a reasonable person to have been aware of the other party's mistake but made no enquiries (see generally Van Rensburg "Die Grondslag van Kontraktuele Gebondenheid" 1986 THRHR 448 454; Van der Merwe, Van Huyssteen, Reinecke and Lubbe Contract: General Principles (2007) 47-48; and Christie 314-322). But in Brink the court conflated the test for the direct reliance theory (authoritatively formulated in Sonap Petroleum (SA) (Pty) Ltd v Pappadogianis 19923 SA 234 (A) 239I-240B) and the iustus error doctrine as follows (par 8):

"The conclusion just reached does not put an end to the enquiry. In view of the decision in this court in Sonap Petroleum (SA) (Pty) Ltd (formerly known as Sonarep (SA) (Pty) Ltd) v Pappadogianis 19923 SA 234 (A) at 240B, it cannot be argued that a signatory's mistake is justifiable simply because it was induced by the other party. The further question must be asked: Would a reasonable man have been misled? It is this objective enquiry which primarily enables a court to prevent abuse of the justus error defence in cases such as the present."

Quite simply, once it is established that a mistake was induced by the contract assertor, the courts have not enquired further whether a reasonable man would have been misled as a separate requirement for the iustus error approach, because reasonable mistake on the part of the contract denier is implicit. Furthermore, the court's approach is potentially confusing, and even elliptical, in that it could suggest that fault on the part of the contract denier would preclude reliance on reasonable mistake; yet in Brink the contract denier was clearly negligent but was nevertheless exonerated from contractual liability on the basis of excusable error (see Hutchison 51-52; for further analysis of this aspect of the decision see Bhana and Nortjé 2005 Annual Survey 211-212; and Pretorius 2006 THRHR 677-680). Suffice to say that the Brink decision deviated in its statement and even application of the law to an extent; however, the real question for present purposes was whether the courts would embrace the more lenient approach it portended or would find a means to avoid applying it. There were conflicting provincial 
decisions, but Brink was delivered at the elevated level of the Supreme Court of Appeal and would henceforth be binding unless overruled by the same court or the Constitutional Court.

\section{$7 \quad$ Caveat subscriptor generally in recent case law}

Recent case law generally dealing with the caveat subscriptor rule clearly reflects the more traditional stance to its application in the interest of preserving certainty in market relations (see also Pretorius 2007 Annual Survey 472-479). Of particular interest is the decision in Hartley $v$ Pyramid Freight (Pty) Ltd t/a Sun Couriers (2007 2 SA 599 (SCA)) (for a discussion of this case see Barnard-Naudé "The Decision in Hartley $v$ Pyramid Freight (Pty) Ltd: Justice Miscarried?" 2007 Stell LR 497). The appellant entered into a contract with the respondent to convey travellers' cheques on his behalf, which the respondent subsequently lost. The appellant sued for their value and the respondent relied on an exemption clause contained in its standard contract excluding it from liability for loss or damage to such items. The appellant contended that he had been unaware of the clause in question and never intended to exempt the respondent from liability. He had not read the terms of the carriage document and his wife had signed it on his behalf. The trial court dismissed the claim (par 1-5).

On appeal to the Supreme Court of Appeal, the gist of the appellant's case was that the respondent's representative knew, or ought reasonably to have known, that the appellant was contracting under the mistaken belief that the respondent would be liable if the travellers' cheques were lost. The essence of this contention was that the respondent could not rely on the doctrine of quasi-mutual assent (which the court equated to the caveat subscriptor rule $-601 \mathrm{H}$ ) in attempting to hold the appellant to the exclusionary clause (par 7) (see generally Sonap Petroleum (SA) (Pty) Ltd v Pappadogianis supra 240J-241D; and further Pretorius "Reasonable Reliance and the Duty to Enquire: Bam v Rafedam Boerdery BK 20041 SA 484 (O)" 2005 THRHR 122 126-131). However, Cloete JA (who also delivered the majority judgment in Brink $v$ Humphries \& Jewell (Pty) Ltd supra), in dismissing the appeal, concluded that the appellant was indifferent to and did not bother to read the conditions of carriage. In consequence, there was no obligation on the part of the respondent's representative to point out the possible consequences of the document and the appellant was bound by it (par 9-10).

Although the respective outcomes of Hartley and Brink are different these cases reveal more than a superficial resemblance: In Brink the contract denier was a brilliant businessman, in Hartley an experienced attorney. Both did not bother to read documents from which they would have gleaned important information at a glance. Both cases hinged on the enforcement of rather harsh provisions (in Brink a suretyship clause, in Hartley an exclusionary clause). The only possible, but unarticulated, difference could be that in Brink the court's paternalistic approach was motivated by a perceived need to police the potential abuse of suretyship clauses in contracts more closely (cf Davids v Absa Bank Bpk 20053 SA 361 (C) 371G-H; and Hutchison 58)). Yet, paradoxically, in Hartley Cloete JA considered that a degree of paternalism in the law of contract would be at 
odds with the caveat subscriptor rule (603E-F). In final analysis, in Hartley the Supreme Court of Appeal followed the stricter, traditional approach to the caveat subscriptor rule, while in Brink this court affirmed the more lenient approach adopted in Keens Group Co (Pty Ltd v Lötter (supra), despite the highlighted similarities between the two cases (see further Pretorius 2007 Annual Survey 473-475).

The provincial divisions have also not been eager to deviate from the general notion that a person will not be relieved from contractual responsibility lightly in terms of the caveat subscriptor rule due to operative mistake (see eg, Absa Bank Ltd v Erasmus 20072 SA 548 (C) par 10; Dole South Africa (Pty) Ltd v Pieter Beukes (Pty) Ltd 20074 SA 577 (C) par 49 (see Pretorius 2007 Annual Survey 476-479 for a discussion of these cases); and Kuehne \& Nagel (Pty) Ltd v Breathetex Corporation (Pty) Ltd [2008] 2 All SA 446 (SE) par 9). Recent instances where the signatory of a contractual document has escaped the reach of the caveat subscriptor rule are clearly in the minority (see eg, Mercurius Motors v Lopez 20083 SA 572 $(\mathrm{SCA})$ ).

\section{Caveat subscriptor and suretyships in recent case law}

In so far suretyships in credit applications and other contractual documents are concerned, the traditional approach to the caveat subscriptor rule also remains evident in positive law. For example, in Langeveld $v$ Union Finance Holdings (Pty) Ltd (2007 4 SA 572 (W)) an accomplished businesswoman signed a lease agreement, which contained a personal suretyship clause, on behalf of a close corporation of which she was the sole member. When held liable on the basis of the suretyship, she claimed that she had signed the document in a hurry, without being made aware of the fact that it contained a suretyship provision and that she would not have signed had she been aware of that fact. On appeal from judgment given against her in a magistrates' court, the court pointed out that the signatory's conduct attracted the attentions of the caveat subscriptor rule (par 12), and held that she was bound to the suretyship for failing to discharge the onus of proving that she was unaware that she was signing a surety undertaking (par 13). Unfortunately, in this regard the court relied on the questionable approach adopted in Stiff $v$ Q Data Distribution (Pty) Ltd (supra), and the criticism levelled at that case applies in equal measure (see further Pretorius 2007 Annual Survey 475-476; and cf Christie 175). Notably though, the signatory was held liable without as much as a mention of Brink $v$ Humphries \& Jewell (Pty) Ltd (supra) and in fairly similar circumstances.

A recent decision practically on all fours with Brink is Royal Canin South Africa (Pty) Ltd $v$ Cooper (2008 6 SA 644 (SE)). The two members of a close corporation executed a credit application which contained a suretyship provision binding the signatories for the obligations and indebtedness of the close corporation to the creditor. In an application for judgment against the signatories as sureties, they countered that although the credit application had been signed by them, they were lay people and would never have realised that the document contained a suretyship clause by reading it in the 
ordinary course. Furthermore, that the suretyship had been "disguised and embedded in the document in order to elicit personal liability in circumstances that are completely unreasonable and untoward" (par 4). The signatories relied directly on Brink in support of their defence that the suretyship was void $a b$ initio. In this regard they sought to draw parallels between their situation and that in Brink, concluding that the concealment of the suretyship was even greater than in the latter case.

In deliberating upon the signatories' defence of iustus error as applied in Brink, Nepgen $\mathrm{J}$ noted as follows regarding the document in which the suretyship was incorporated (par 7):

"The question that must therefore be decided is whether the allegations made by the respondents [signatories] indicate that as a result of a misrepresentation made by the applicant [creditor] they were reasonably misled into believing that the document was an application for credit and nothing more. I have no doubt that the document is misleading in the extreme. There is nothing to indicate that it contains a suretyship clause. In fact, as was pointed out on behalf of the respondents, the suretyship obligation is contained in a sentence which commences with an acknowledgment that the terms and conditions ... have been read and understood. Apart from the words that follow, there is no indication that any further obligation is being imposed upon the signatories thereof. I also agree with the submission that the document is more misleading than that with which the Brink case was concerned."

Despite this revelation Nepgen $\mathrm{J}$ was not prepared to let the signatories off that lightly and, to this end, he proceeded to distinguish Brink on the facts. In answering the question whether the lack of awareness by the signatories of the suretyship contained in the document was reasonable, he noted that significantly the signatories had failed to allege that the document had not been read by them and concluded that they in fact had read it (contrast Brink par 6-7). This being so, he continued, they must have been aware that the suretyship imposed some form of liability. If they did not precisely understand the import of the suretyship then, as reasonable people, they should have sought legal advice (contrast Brink par 11-12). Nepgen $\mathrm{J}$ also noted that the signatories failed to allege that they would not have signed the form if they realised that it contained a personal suretyship provision (contrast Brink par 6). In consequence, the defence of iustus error could not succeed (par 8).

It is suggested that the distinctions drawn by the court with Brink, so as not to apply it, are more illusory than real. There seems to be no real difference between negligently causing one's own mistake regarding the content of a contractual document by not reading it (compare the classic case of George $v$ Fairmead (Pty) Ltd supra), or reading it without comprehension and not bothering to find out what it means (as in the present instance). It is also by no means clear that the signatories did in fact read the document. Furthermore, a defence of iustus error, which relates to the materiality as well as the reasonabless of a mistake (see Van der Merwe et al 45-47), surely implies that the signatories would not have signed the contract had they understood that it contained a personal suretyship clause. Rather it seems that the court had a clear notion of which direction the matter should take, but had to find the means to circumvent Brink. However, there appears to be no material distinction between the two cases and Brink should have been applied; the circumstances surrounding the signing of the document were very similar to those in Brink, but a fortiori two signatories 
had the opportunity to peruse the document before signing it and the document was even more misleading than the one in Brink.

Finally, regarding recent case law, mention may be made of the matter of Cecil Nurse (Pty) Ltd v Nkola (2008 2 SA 441 (SCA)). Here the sole director and shareholder of a private company separately executed a credit application on behalf of the company and a personal suretyship securing the debts of the company to the creditor. As is invariably the case, all went well until the company could not meet its obligations and the director was sued on the basis of the suretyship. The director countered that the suretyship had mistakenly been sent by his assistant to the creditor in his absence and that he was in the process of negotiating a limitation on his liability in terms thereof. He further sought to rely on an amended suretyship which limited his liability. The court appropriately found that the signed suretyship was valid on the basis of the reliance theory with reference to the seminal decisions in Smith $v$ Hughes ((1871) LR 6 QB 597 607) and Sonap Petroleum (SA) (Pty) Ltd v Pappadogianis (supra 239-240 par 15-16). The amended suretyship merely amounted to a proposed amendment to the existing suretyship, which did not come to fruition (446-447). Although there is a degree of distinction with Brink on the facts, this decision is nevertheless pertinent in that it is consonant with the traditional application of the caveat subscriptor rule (although the rule was not mentioned as such), as opposed to the more lenient approach displayed in Brink. The Supreme Court of Appeal was prepared to take a fairly hard line against a director who was willing to accept credit on behalf of his company, but was not prepared to stand in for the debts of the company so incurred when for all objective purposes he had agreed to do so.

\section{$9 \quad$ Concluding observations}

The most obvious observation arising from the preceding discussion is that Brink $v$ Humphries \& Jewell (Pty) Ltd (supra) has not directly been applied in circumstances when, it is submitted, it should have (Royal Canin South Africa (Pty) Ltd $v$ Cooper supra). Moreover, the more lenient approach taken in Brink has yet to find favour with the courts (compare generally Langeveld $v$ Union Finance Holdings (Pty) Ltd supra; and Cecil Nurse (Pty) Ltd v Nkola supra), who seem to prefer a fairly strict application of the caveat subscriptor rule in circumstances where signatories have undertaken personal suretyships for credit extended to the corporate entities which they represent. In other matters, the courts have likewise remained true to the traditional sentiment that a person will not lightly be relieved from liability under a contract which he or she has signed (compare eg, Hartley $v$ Pyramid Freight (Pty) Ltd t/a Sun Couriers supra; Absa Bank Ltd v Erasmus supra; Dole South Africa (Pty) Ltd v Pieter Beukes (Pty) Ltd supra; and Kuehne \& Nagel (Pty) Ltd v Breathetex Corporation (Pty) Ltd supra).

From a conceptual viewpoint it is noteworthy that the courts also have not as yet embraced the re-formulation of the iustus error approach in Brink, which entails a rather problematic conflation of the direct reliance theory (doctrine of quasi-mutual assent) and its indirect counterpart (iustus error doctrine). Of course legal doctrine must develop to make provision for novel instances (cf Floyd and Pretorius "A Reconciliation of the Different 
Approaches to Contractual Liability in the Absence of Consensus: Sonap Petroleum (formerly known as Sonarep) (SA) (Pty) Ltd v Pappadogianis 19923 SA 234 (A)" 1992 THRHR 668 672-673), but needless reformulations run the risk of upsetting the balance which has been developed in case law and are best avoided (see Hutchison 51-52; and compare eg, the re-formulation of the test for reliance seemingly within the context of iustus error in Prins v Absa Bank Ltd 19983 SA 904 (C) 909B-D; and justified criticism thereof in Davids v Absa Bank Bpk supra par 15).

It further remains questionable to accept (as was done in Brink (par 9)) that a suretyship clause may not reasonably be expected to form part of a credit application on behalf of a corporate entity (see minority decision in Brink par 35; Roomer v Wedge Steel (Pty) Ltd supra 543F-G; Sharrock 1989 SALJ 463; Otto 2005 TSAR 814; and cf Bhana and Nortjé 2005 Annual Survey 212). A clause which reasonably may be expected to form part of a contract does not have to be pointed out by the contract assertor (Afrox Healthcare Bpk v Strydom 20026 SA 21 (SCA) 41-42; and cf Potgieter v British Airways plc 20053 SA 133 (C) 140), and it is suggested that personal suretyships are very much a part of such credit applications, simply because of the risk which the creditor exposes itself to (see generally Otto 2005 $T S A R$ 806-807). A burgeoning body of case law is an indication of how frequently corporate entities are unable to service their debts, which is exactly the contingency that creditors seek to provide for by way of suretyships inserted in credit applications. After all, why should creditors bear the risk when credit is sought at the instance of individuals who probably know better than anyone else the financial situation of the corporate entities which they represent?

All told, although the spectre of Brink lurks to haunt creditors, and no doubt signatories of suretyships will be sure to invoke it at every opportunity, the courts have not been keen to apply it (see generally Pretorius 2007 Annual Survey 472-479; and cf Otto 2005 TSAR 812-814). There probably is a need for the courts to police suretyships more closely (cf Davids v Absa Bank Bpk supra $371 \mathrm{G}-\mathrm{H}$ ), but where directors and members respectively of companies and close corporations do not bother to acquaint themselves with the terms on which credit may be granted, and there is no untoward conduct on the part of the creditor, the need for protection against suretyships in credit applications on behalf of corporate entities certainly seems to diminish. One of the main concerns with Brink is the "very low level of selfprotecting behaviour that is apparently expected from the signatory" (Bhana and Nortjé 2005 Annual Survey 212). This concern is exacerbated where the signatory is an experienced businessman who reasonably ought to be aware of the pitfalls of contracts normally concluded in the course of his company's business (as in eg, Brink). As cautioned by Hutchison (47), "where the signatory is a person with considerable business experience, reliance on the signature as an indicator of consent must as a general rule surely still be reasonable if the maxim caveat subscriptor is to have any real meaning". Of course all relevant circumstances should be taken into account in determining whether a material mistake is reasonable or not, and consequently the situation may be different, for instance, where the signatory does not occupy a prominent position in a company (compare eg, Kempston Hire (Pty) Ltd $v$ Snyman supra) or the contract is rather technical 
and novel in nature (cf Constantia Insurance Co Ltd $v$ Compusource (Pty) Ltd 20054 SA 345 (SCA)). Nevertheless, it seems that on the whole the courts still generally show a preference for the stricter, traditional approach to balancing the caveat subscriptor rule and iustus error doctrine than was the case in Brink and, it is suggested, rightly so.

C-J Pretorius

University of South Africa (UNISA) 